J Trace Elem Med Biol. 2012 June ; 26(0): 137-140. doi:10.1016/j.jtemb.2012.03.004.

\title{
Thyroid function in pregnancy
}

\author{
Angela M. Leung, MD, MSc \\ Boston University School of Medicine, Section of Endocrinology, Diabetes, and Nutrition, 88 East \\ Newton Street, Evans 201, Boston, MA, USA
}

\begin{abstract}
Iodine is required for the production of thyroid hormones. Normal thyroid function during pregnancy is important for both the mother and developing fetus. This review discusses the changes in thyroid physiology that occur during pregnancy, the significance of thyroid function tests and thyroid antibody titers assessed during pregnancy, and the potential obstetric complications associated with maternal hypothyroidism.
\end{abstract}

\section{Keywords}

Thyroid; Pregnancy

\section{Changes in thyroid physiology during pregnancy}

Iodine is an essential component of the thyroid hormones, triiodothyronine (T3) and thyroxine (T4), produced by the thyroid gland. The fetal thyroid does not begin to concentrate iodine until 10-12 weeks of gestation, and the synthesis and secretion of thyroid hormone controlled by fetal pituitary thyroid stimulating hormone (TSH) ensues at approximately 20 weeks of gestation [1]. As such, particularly during early pregnancy, the fetus is reliant on maternal thyroxine, which cross the placenta in small quantities to maintain normal fetal thyroid function. At birth, approximately $30 \%$ of the T4 in cord blood originates from the infant's mother [2].

$\mathrm{T} 3$ is the active thyroid hormone, and approximately $80 \%$ of $\mathrm{T} 3$ is produced from the deiodination of $\mathrm{T} 4$ in the liver, muscle, and other tissues. The binding of T3 to thyroid hormone receptors in various peripheral target tissues are important for the regulation of the body's metabolism. Approximately $99.97 \%$ of T4 and $99.7 \%$ of T3 is protein-bound, primarily to thyroid hormone binding globulin (TBG), and in lesser amounts, to albumin and transthyretin (the latter for $\mathrm{T} 4$ only). Beginning in early pregnancy, rising maternal estradiol levels result in increased sialyation and glycosylation of TBG in the liver [3,4]. This decreases the peripheral metabolism of TBG to result in an approximate 1.5-2 fold sustained rise in serum TBG levels compared to euthyroid non-pregnant women $[5,6]$, thereby

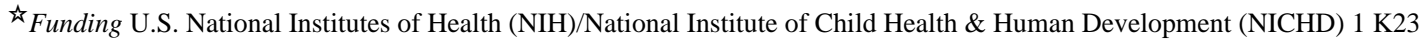
HD068552 01.

(C) 2012 Elsevier GmbH. All rights reserved

Angela.Leung@bmc.org.
} 
creating an increased need for T3 and T4 production throughout pregnancy. Other reasons for the increased maternal thyroid hormone demands during pregnancy include the increased degradation of $\mathrm{T} 4$ and $\mathrm{T} 3$ by the type 3 inner ring deiodinase abundantly expressed in the placenta, chorion, and amnion to generate inactive iodothyronine (reverse T3) [7]; the higher volume of T4 distribution due to an increased plasma volume during pregnancy; the minimal transfer of T4 from the mother to the fetus via the placenta; and the effect of serum human chorionic gonadotropin (hCG) during pregnancy.

Serum hCG is a glycoprotein produced primarily by the placenta and peaks at the end of the first trimester of pregnancy. It binds to the TSH receptor on the thyroid cell membrane and is a weak stimulator, resulting in increased secretion of T4 and T3 and partial suppression of serum TSH. Due to the effects of hCG, the lower range of serum TSH is decreased in pregnancy [8]. The higher serum hCG concentrations seen in multiple gestation pregnancies is associated with an even greater degree of TSH suppression; maternal serum TSH concentrations are lower in twin pregnancies, compared to a singleton pregnancy, and even lower in triplet or quadruplet pregnancies [9]. One report has suggested that women with lower TSH concentrations in early pregnancy are more susceptible to TSH suppression by any hCG level [10]. In a study of 63 pregnant women with serum hCG levels $>400,000$ IU/L, TSH was suppressed in the entire cohort, with the majority lacking symptoms of hyperthyroidism [11].

Although the lower limit for serum TSH in pregnant women should be lower than in the non-pregnant population, there are limited data reporting the specific parameters of the TSH reference range during pregnancy. Recent studies have suggested that the $95 \%$ confidence interval for first trimester TSH values in women without thyroid disease is $0.03-2.5 \mathrm{mIU} / \mathrm{L}$ [12-15], although the findings in some of these and other studies may have been influenced by mild population iodine deficiency and/or maternal thyroid antibody positivity, both factors which may influence thyroid function. Until further data is available, expert opinion has advocated the following trimester-specific recommendations for TSH reference ranges during pregnancy: $0.1-2.5 \mathrm{mIU} / \mathrm{L}$ (first trimester), $0.2-0.3 \mathrm{mIU} / \mathrm{L}$ (second trimester), and 0.3-3.0 mIU/L (third trimester) [16,17].

Measurement of serum free T4 concentrations can be combined with assessment of TSH to assess thyroid function. However, during the first trimester of pregnancy, free T4 levels measured by analog immunoassays may be unreliable, as measurements using 2 different assays were not reproducible in a recent study [18]. Similarly, there are no trimester-specific pregnancy reference ranges for free T4 assays, and available commercial assays may underestimate or overestimate free T4 concentrations in pregnant women [19]. Free T4 measurements obtained indirectly by the free $\mathrm{T} 4$ index and directly by equilibrium dialysis and ultrafiltration, and if available, by solid phase extraction-liquid chromatography/tandem mass spectrometry (LC/MS/MS), may provide more reliable estimates of thyroid function during pregnancy [16]. During pregnancy, total T4 levels are appropriately elevated above the non-pregnant reference range, due to the increased serum TBG levels throughout gestation [18]. 


\section{Maternal hypothyroidism and obstetric complications}

Maternal hypothyroidism occurs in an estimated $2.5 \%$ of all U.S. pregnant women [20]. In an observational study of over 9000 U.S. women with singleton pregnancies, $2.2 \%$ of women had a TSH $\geq 6 \mathrm{mIU} / \mathrm{L}$ and $0.4 \%$ of women had a TSH $\geq 10 \mathrm{mIU} / \mathrm{L}$ between 15 and 18 weeks of gestation [21]. Overt hypothyroidism is classified as an elevated serum TSH with low serum FT4, while subclinical hypothyrodism is defined as an elevated serum TSH with normal serum FT4. Isolated hypothyroxinemia is characterized by a normal serum TSH and low serum FT4 levels.

The association between overt maternal hypothyroidism, particularly in early pregnancy, and adverse obstetric outcomes is well-established. In a study of women during the second trimester of pregnancy, the prevalence of fetal death was over 4-fold higher in mothers with a TSH concentration $\geq 6 \mathrm{mIU} / \mathrm{L}$, compared to those who mothers had a TSH $<6 \mathrm{mIU} / \mathrm{L}$ (3.8\% vs. $0.9 \%$ ) [21]. Among women with an increased TSH $>10 \mathrm{mU} / \mathrm{L}$, the prevalence of fetal death rose to $8.1 \%$ [21]. Correction of hypothyroidism during pregnancy with levothyroxine administration may improve these outcomes. One study reported that $60 \%$ of overtly hypothyroid women and $71.4 \%$ of subclinically hypothyroid women who were inadequately treated with levothyroxine had a miscarriage, while $100 \%$ of overtly hypothyroid women and $90.5 \%$ of subclinically hypothyroid women who were adequately treated with levothyroxine carried their pregnancies to term [22]. Maternal overt hypothyroidism has also been associated with a higher risk of gestational hypertension (ecclampsia, preeclampsia, and pregnancy-induced hypertension) [23], very preterm birth [24], breech delivery [25], and low birth weight [23].

A relationship between subclinical maternal hypothyroidism and obstetric complications has also been reported. In a retrospective study by Casey and colleagues of over 17,000 pregnant women, women with subclinical hypothyroidism (present in $2.3 \%$ of the cohort) had 2-3 fold increased risks of pregnancy-related complications, including placental abruption, preterm delivery, admissions to the neonatal intensive care unit, and infant respiratory distress syndrome, compared to the euthyroid mothers [26]. Negro et al. reported a higher proportion of pregnancy loss in women with a serum TSH between 2.5 and $5.0 \mathrm{mIU} / \mathrm{L}$, compared to women with a TSH $<2.5 \mathrm{mIU} / \mathrm{L}$, during the first trimester [27]. Another recent study demonstrated that fetal death was associated with maternal serum TSH levels $>97.5$ th percentile and FT4 levels <2.5th percentile between 11 and 13 weeks of gestation [28]. Benhadi et al. reported a positive linear relationship between log-transformed TSH concentrations, obtained at the first obstetrical visit (average 13 weeks) and miscarriage in over 2500 Dutch women [29]. De Vivo et al. reported that among women who miscarried before 12 weeks of gestation, fetal loss occurred earlier in those with subclinical hypothyroidism than euthyroid women (6.5 vs. 8.2 weeks gestational age) [30]. A recent meta-analysis demonstrated that maternal subclinical hypothyroidism was also associated with increased odds of preeclampsia and perinatal mortality [31].

Others have found no associations between mild maternal hypothyroidism during pregnancy and a variety of adverse obstetric outcomes, including premature birth, low APGAR scores, and fetal death [32-34]. Wang et al. reported an association between subclinical 
hypothyroidism and increased risk of spontaneous abortions, but not with gestational hypertension, premature delivery, anemia, postpartum hemorrhage, low APGAR scores, and low birth weight [35]. In another study, risks of adverse pregnancy outcomes were not increased in over 200 pregnant women with isolated hypothyroxinemia [36].

\section{Maternal thyroid antibodies and obstetric complications}

Serum thyroid antibody positivity is common among women of childbearing age and may be associated with abnormal thyroid function. Serum anti-thyroglobulin antibodies and antithyroid peroxidase (TPO) antibodies, found in $10-11 \%$ of the general U.S. population, are more prevalent in women and in older age [37]. A recent study found that $6 \%$ of over 17,000 women before the 20th week of gestation had positive TPO antibodies [38]. In a cohort of first-trimester pregnant women, those with positive TPO antibodies had higher serum TSH, a lower FT4 index, and lower T4 levels compared to women with negative TPO antibodies [12], findings consistent with those of other studies [15,39].

The first report of an increased miscarriage risk associated with anti-thyroid antibodies was published in 1990 [40]. In that study, fetal loss occurred in 17\% of TPO-positive pregnant women, significantly higher than its prevalence in TPO-negative pregnant women (8.4\%), during the first trimester [40]. Since then, multiple observational studies have confirmed a 2-4 fold risk of miscarriage among euthyroid TPO antibody-positive women, compared to euthyroid TPO antibody-negative women [38,41-43], including 2 meta-analyses [44,45]. Some [46,47], but not all [48-50], studies have also found associations between thyroid autoimmunity and increased rates of recurrent miscarriage. A 2-3 fold increase in the rate of miscarriage in women with TPO antibodies undergoing assistive reproductive technology has been seen in several studies [51-56]. The presence of maternal thyroid antibodies has also been associated with a 3-fold risk for premature delivery before 37 weeks gestation [57], postpartum thyroiditis [58], thyroiditis after pregnancy loss [59], and placental abruption [38].

The reasons for the associations between anti-thyroid antibodies and obstetric complications remain unclear. They may be related to a direct effect of the anti-thyroid antibodies, or the anti-thyroid antibodies may serve as a marker for other causative autoimmune syndromes. Alternatively, anti-thyroid antibodies may simply indicate limited thyroid functional reserve [5], suggesting that the association between TPO antibody positivity and obstetric complications may be confounded by even mild hypothyroidism obtained during pregnancy.

There has been one randomized clinical trial demonstrating that the risk of miscarriage and premature delivery in euthyroid TPO-positive pregnant women may be attenuated by the administration of levothyroxine [57]. In this study, 57 euthyroid pregnant TPO antibodypositive women were administered $0.5-1.0 \mu \mathrm{g} / \mathrm{kg} / \mathrm{day}$ levothyroxine beginning in the first trimester and maintained throughout pregnancy. There was a lower risk of premature birth among the treated women (compared to the untreated 58 euthyroid TPO antibody-positive women) and miscarriage (compared to the untreated 869 euthyroid TPO-negative women). One of the major limitations to this study is the mildly increased serum TSH concentrations 
at baseline among the women with positive TPO antibodies. The findings are novel, but have as yet not been replicated.

\section{Thyroid function and antibody testing during pregnancy}

The consideration of whether or not all pregnant women should be screened with thyroid function tests and/or tests for anti-thyroid antibodies remains extremely controversial. We recently reported a high rate of thyroid function screening during pregnancy at our institution [60]. However, the aforementioned limitations and others surrounding thyroid function screening during pregnancy have resulted in the development of varying expert recommendations. The American Association of Clinical Endocrinologists has recommended routine TSH screening before pregnancy or during the first trimester in all pregnant women [61]. The American College of Obstetricians and Gynecologists (ACOG) has recommended against serum TSH testing in asymptomatic pregnant women [62]. Recent guidelines from the Endocrine Society and the American Thyroid Association recommend aggressive case-finding, but not screening, among pregnant women [16,63]. However, casefinding in pregnant women has limitations; it has been reported that screening pregnant women with a family or personal history of thyroid disease or other autoimmune disease, would fail to identify $30 \%$ of women with overt or subclinical hypothyroidism [64], in contrast to a recent report suggesting no difference in adverse obstetric outcomes between case-finding and universal screening of thyroid function during pregnancy [65].

Assessment of thyroid function during pregnancy remains a controversial issue. Further research is needed to better elucidate the relationships between overt and subclinical maternal hypothyroidism, maternal thyroid antibody positivity, and obstetric complications. However, in the interim, given the potential obstetric and neonatal complications of untreated thyroid disorders in pregnancy, we recommend determining the presence of maternal thyroid dysfunction as early as possible in pregnancy.

\section{Conclusions}

Thyroid hormone production increases in pregnancy and requires increased iodine intake. Serum TSH concentrations should be interpreted in the context of pregnancy physiology. Thyroid function and thyroid antibody screening during pregnancy is controversial. Further research is needed to determine whether mild maternal hypothyroidism or positive thyroid antibodies are associated with obstetric complications.

\section{References}

1. Brown RS. Minireview: developmental regulation of thyrotropin receptor gene expression in the fetal and newborn thyroid. Endocrinology. 2004; 145(9):4058-61. [PubMed: 15231704]

2. Fisher DA. Fetal thyroid function: diagnosis and management of fetal thyroid disorders. Clin Obstet Gynecol. 1997; 40(1):16-31. [PubMed: 9103947]

3. Ain KB, Mori Y, Refetoff S. Reduced clearance rate of thyroxine-binding globulin (TBG) with increased sialylation: a mechanism for estrogen-induced elevation of serum TBG concentration. J Clin Endocrinol Metab. 1987; 65(4):689-96. [PubMed: 3116030]

4. Pittas, AG.; Lee, SL. Evaluation of thyroid function. In: Hall, JE.; Niemann, LK., editors. Handbook of diagnostic endocrinology. Humana Press Inc; Totowa, New Jersey: 2003. p. 112 
5. Glinoer D. The regulation of thyroid function in pregnancy: pathways of endocrine adaptation from physiology to pathology. Endocr Rev. 1997; 18(3):404-33. [PubMed: 9183570]

6. Mandel SJ, Spencer CA, Hollowell JG. Are detection and treatment of thyroid insufficiency in pregnancy feasible? Thyroid. 2005; 15(1):44-53. [PubMed: 15687823]

7. Roti E, Fang SL, Emerson CH, Braverman LE. Placental inner ring iodothyronine deiodination: a mechanism for decreased passage of T4 and T3 from mother to fetus. Trans Assoc Am Physicians. 1981; 94:183-9. [PubMed: 7344219]

8. Glinoer D, de Nayer P, Bourdoux P, Lemone M, Robyn C, van Steirteghem A, et al. Regulation of maternal thyroid during pregnancy. J Clin Endocrinol Metab. 1990; 71(2):276-87. [PubMed: 2116437]

9. Grun JP, Meuris S, De Nayer P, Glinoer D. The thyrotrophic role of human chorionic gonadotrophin (hCG) in the early stages of twin (versus single) pregnancies. Clin Endocrinol (Oxf). 1997; 46(6): 719-25. [PubMed: 9274703]

10. Haddow JE, McClain MR, Lambert-Messerlian G, Palomaki GE, Canick JA, Cleary-Goldman J, et al. First and Second Trimester Evaluation of Risk for Fetal Aneuploidy Research Consortium. Variability in thyroid-stimulating hormone suppression by human chorionic [corrected] gonadotropin during early pregnancy. J Clin Endocrinol Metab. 2008; 93(9):3341-7. [PubMed: 18544616]

11. Lockwood CM, Grenache DG, Gronowski AM. Serum human chorionic gonadotropin concentrations greater than 400,000 IU/L are invariably associated with suppressed serum thyrotropin concentrations. Thyroid. 2009; 19(8):863-8. [PubMed: 19505185]

12. Pearce EN, Oken E, Gillman MW, Lee SL, Magnani B, Platek D, et al. Association of firsttrimester thyroid function test values with thyroperoxidase antibody status, smoking, and multivitamin use. Endocr Pract. 2008; 14(1):33-9. [PubMed: 18238739]

13. Panesar NS, Li CY, Rogers MS. Reference intervals for thyroid hormones in pregnant Chinese women. Ann Clin Biochem. 2001; 38:329-32. Pt 4. [PubMed: 11471873]

14. McClain MR, Lambert-Messerlian G, Haddow JE, Palomaki GE, Canick JA, Cleary-Goldman J, et al. FaSTER Research Consortium. Sequential first- and second-trimester TSH, free thyroxine, and thyroid antibody measurements in women with known hypothyroidism: a FaSTER trial study. Am J Obstet Gynecol. 2008; 199(2):129. e1-129.e6. [PubMed: 18448078]

15. Spencer C, Lee R, Kazarosyan M, Bergoglio L, Braverman L, Mereshian P, et al. Thyroid reference ranges in pregnancy: studies on an iodine sufficient cohort. Thyroid. 2005; 15(Suppl. 1):S16.

16. Stagnaro-Green A, Abalovich M, Alexander E, Azizi F, Mestman J, Negro R, et al. American Thyroid Association Taskforce on Thyroid Disease During Pregnancy and Postpartum. Guidelines of the American Thyroid Association for the diagnosis and management of thyroid disease during pregnancy and postpartum. Thyroid. 2011; 21(10):1081-125. [PubMed: 21787128]

17. Mannisto T, Surcel HM, Ruokonen A, Vaarasmaki M, Pouta A, Bloigu A, et al. Early pregnancy reference intervals of thyroid hormone concentrations in a thyroid antibody-negative pregnant population. Thyroid. 2011; 21(3):291-8. [PubMed: 21254924]

18. Lee RH, Spencer CA, Mestman JH, Miller EA, Petrovic I, Braverman LE, et al. Free T4 immunoassays are flawed during pregnancy. Am J Obstet Gynecol. 2009; 200(3):260. e1-260.e6. [PubMed: 19114271]

19. Sapin R, D’Herbomez M, Schlienger JL. Free thyroxine measured with equilibrium dialysis and nine immunoassays decreases in late pregnancy. Clin Lab. 2004; 50(9-10):581-4. [PubMed: 15481634]

20. Klein RZ, Haddow JE, Faix JD, Brown RS, Hermos RJ, Pulkkinen A, et al. Prevalence of thyroid deficiency in pregnant women. Clin Endocrinol (Oxf). 1991; 35(1):41-6. [PubMed: 1889138]

21. Allan WC, Haddow JE, Palomaki GE, Williams JR, Mitchell ML, Hermos RJ, et al. Maternal thyroid deficiency and pregnancy complications: implications for population screening. J Med Screen. 2000; 7(3):127-30. [PubMed: 11126160]

22. Abalovich M, Gutierrez S, Alcaraz G, Maccallini G, Garcia A, Levalle O. Overt and subclinical hypothyroidism complicating pregnancy. Thyroid. 2002; 12(1):63-8. [PubMed: 11838732] 
23. Leung AS, Millar LK, Koonings PP, Montoro M, Mestman JH. Perinatal outcome in hypothyroid pregnancies. Obstet Gynecol. 1993; 81(3):349-53. [PubMed: 8437784]

24. Stagnaro-Green A, Chen X, Bogden JD, Davies TF, Scholl TO. The thyroid and pregnancy: a novel risk factor for very preterm delivery. Thyroid. 2005; 15(4):351-7. [PubMed: 15876159]

25. Kuppens SM, Kooistra L, Wijnen HA, Crawford S, Vader HL, Hasaart TH, et al. Maternal thyroid function during gestation is related to breech presentation at term. Clin Endocrinol (Oxf). 2010; 72:820-4. [PubMed: 19832853]

26. Casey BM, Dashe JS, Wells CE, McIntire DD, Byrd W, Leveno KJ, et al. Subclinical hypothyroidism and pregnancy outcomes. Obstet Gynecol. 2005; 105(2):239-45. [PubMed: 15684146]

27. Negro R, Schwartz A, Gismondi R, Tinelli A, Mangieri T, Stagnaro-Green A. Increased pregnancy loss rate in thyroid antibody negative women with TSH levels between 2.5 and 5.0 in the first trimester of pregnancy. J Clin Endocrinol Metab. 2010; 95(9):E44-8. [PubMed: 20534758]

28. Ashoor G, Maiz N, Rotas M, Jawdat F, Nicolaides KH. Maternal thyroid function at 11 to 13 weeks of gestation and subsequent fetal death. Thyroid. 2010; 20(9):989-93. [PubMed: 20718684]

29. Benhadi N, Wiersinga WM, Reitsma JB, Vrijkotte TG, Bonsel GJ. Higher maternal TSH levels in pregnancy are associated with increased risk for miscarriage, fetal or neonatal death. Eur $\mathbf{J}$ Endocrinol. 2009; 160(6):985-91. [PubMed: 19273570]

30. De Vivo A, Mancuso A, Giacobbe A, Moleti M, Maggio Savasta L, De Dominici R, et al. Thyroid function in women found to have early pregnancy loss. Thyroid. 2010; 20(6):633-7. [PubMed: 20470201]

31. van den Boogaard E, Vissenberg R, Land JA, van Wely M, van der Post JA, Goddijn M, et al. Significance of (sub)clinical thyroid dysfunction and thyroid autoimmunity before conception and in early pregnancy: a systematic review. Hum Reprod Update. 2011; 17(5):605-19. [PubMed: 21622978]

32. Cleary-Goldman J, Malone FD, Lambert-Messerlian G, Sullivan L, Canick J, Porter TF, et al. Maternal thyroid hypofunction and pregnancy outcome. Obstet Gynecol. 2008; 112(1):85-92. [PubMed: 18591312]

33. Mannisto T, Vaarasmaki M, Pouta A, Hartikainen AL, Ruokonen A, Surcel HM, et al. Perinatal outcome of children born to mothers with thyroid dysfunction or antibodies: a prospective population-based cohort study. J Clin Endocrinol Metab. 2009; 94(3):772-9. [PubMed: 19106271]

34. Mannisto T, Vaarasmaki M, Pouta A, Hartikainen AL, Ruokonen A, Surcel HM, et al. Thyroid dysfunction and autoantibodies during pregnancy as predictive factors of pregnancy complications and maternal morbidity in later life. J Clin Endocrinol Metab. 2010; 95(3):1084-94. [PubMed: 20080846]

35. Wang S, Teng WP, Li JX, Wang WW, Shan ZY. Effects of maternal subclinical hypothyroidism on obstetrical outcomes during early pregnancy. J Endocrinol Invest. (Epub ahead of print).

36. Casey BM, Dashe JS, Spong CY, McIntire DD, Leveno KJ, Cunningham GF. Perinatal significance of isolated maternal hypothyroxinemia identified in the first half of pregnancy. Obstet Gynecol. 2007; 109(5):1129-35. [PubMed: 17470594]

37. Hollowell JG, Staehling NW, Flanders WD, Hannon WH, Gunter EW, Spencer CA, et al. T(4), and thyroid antibodies in the United States population (1988 to 1994): National Health and Nutrition Examination Survey (NHANES III). J Clin Endocrinol Metab. 2002; 87(2):489-99. [PubMed: 11836274]

38. Abbassi-Ghanavati M, Casey BM, Spong CY, McIntire DD, Halvorson LM, Cunningham FG. Pregnancy outcomes in women with thyroid peroxidase antibodies. Obstet Gynecol. 2010; 116(2): 381-6. Pt 1. [PubMed: 20664399]

39. Glinoer D, Riahi M, Grun JP, Kinthaert J. Risk of subclinical hypothyroidism in pregnant women with asymptomatic autoimmune thyroid disorders. J Clin Endocrinol Metab. 1994; 9(1):197-204. [PubMed: 8027226]

40. Stagnaro-Green A, Roman SH, Cobin RH, el-Harazy E, Alvarez-Marfany M, Davies TF. Detection of at-risk pregnancy by means of highly sensitive assays for thyroid autoantibodies. JAMA. 1990; 264(11):1422-5. [PubMed: 2118190] 
41. Bagis T, Gokcel A, Saygili ES. Autoimmune thyroid disease in pregnancy and the postpartum period: relationship to spontaneous abortion. Thyroid. 2001; 11(11):1049-53. [PubMed: 11762715]

42. Iijima T, Tada H, Hidaka Y, Mitsuda N, Murata Y, Amino N. Effects of autoantibodies on the course of pregnancy and fetal growth. Obstet Gynecol. 1997; 90(3):364-9. [PubMed: 9277645]

43. Glinoer D, Soto MF, Bourdoux P, Lejeune B, Delange F, Lemone M, et al. Pregnancy in patients with mild thyroid abnormalities: maternal and neonatal repercussions. J Clin Endocrinol Metab. 1991; 73(2):421-7. [PubMed: 1906897]

44. Thangaratinam S, Tan A, Knox E, Kilby MD, Franklyn J, Coomarasamy A. Association between thyroid autoantibodies and miscarriage and preterm birth: meta-analysis of evidence. BMJ. 2011; 342:d2616. [PubMed: 21558126]

45. Prummel MF, Wiersinga WM. Thyroid autoimmunity and miscarriage. Eur J Endocrinol. 2004; 150(6):751-5. [PubMed: 15191343]

46. De Carolis C, Greco E, Guarino MD, Perricone C, Dal Lago A, Giacomelli R, et al. Anti-thyroid antibodies and antiphospholipid syndrome: evidence of reduced fecundity and of poor pregnancy outcome in recurrent spontaneous aborters. Am J Reprod Immunol. 2004; 52(4):263-6. [PubMed: 15494047]

47. Bussen S, Steck T. Thyroid autoantibodies in euthyroid non-pregnant women with recurrent spontaneous abortions. Hum Reprod. 1995; 10(11):2938-40. [PubMed: 8747048]

48. Rushworth FH, Backos M, Rai R, Chilcott IT, Baxter N, Regan L. Prospective pregnancy outcome in untreated recurrent miscarriers with thyroid autoantibodies. Hum Reprod. 2000; 15(7):1637-9. [PubMed: 10875881]

49. Pratt DE, Kaberlein G, Dudkiewicz A, Karande V, Gleicher N. The association of antithyroid antibodies in euthyroid nonpregnant women with recurrent first trimester abortions in the next pregnancy. Fertil Steril. 1993; 60(6):1001-5. [PubMed: 8243677]

50. Esplin MS, Branch DW, Silver R, Stagnaro-Green A. Thyroid autoantibodies are not associated with recurrent pregnancy loss. Am J Obstet Gynecol. 1998; 179(6):1583-6. Pt 1. [PubMed: 9855601]

51. Kim CH, Chae HD, Kang BM, Chang YS. Influence of antithyroid antibodies in euthyroid women on in vitro fertilization-embryo transfer outcome. Am J Reprod Immunol. 1998; 40(1):2-8. [PubMed: 9689353]

52. Negro R, Mangieri T, Coppola L, Presicce G, Casavola EC, Gismondi R, et al. Levothyroxine treatment in thyroid peroxidase antibody-positive women undergoing assisted reproduction technologies: a prospective study. Hum Reprod. 2005; 20(6):1529-33. [PubMed: 15878930]

53. Poppe K, Glinoer D, Tournaye H, Devroey P, van Steirteghem A, Kaufman L, et al. Assisted reproduction and thyroid autoimmunity: an unfortunate combination? J Clin Endocrinol Metab. 2003; 88(9):4149-52. [PubMed: 12970279]

54. Muller AF, Verhoeff A, Mantel MJ, Berghout A. Thyroid autoimmunity and abortion: a prospective study in women undergoing in vitro fertilization. Fertil Steril. 1999; 71(1):30-4. [PubMed: 9935112]

55. Singh A, Dantas ZN, Stone SC, Asch RH. Presence of thyroid antibodies in early reproductive failure: biochemical versus clinical pregnancies. Fertil Steril. 1995; 63(2):277-81. [PubMed: 7843431]

56. Kutteh WH, Schoolcraft WB, Scott RT Jr. Antithyroid antibodies do not affect pregnancy outcome in women undergoing assisted reproduction. Hum Reprod. 1999; 14(11):2886-90. [PubMed: 10548642]

57. Negro R, Formoso G, Mangieri T, Pezzarossa A, Dazzi D, Hassan H. Levothyroxine treatment in euthyroid pregnant women with autoimmune thyroid disease: effects on obstetrical complications. J Clin Endocrinol Metab. 2006; 91(7):2587-91. [PubMed: 16621910]

58. Pearce EN, Farwell AP, Braverman LE. Thyroiditis. N Engl J Med. 2003; 348(26):2646-55. [PubMed: 12826640]

59. Marqusee E, Hill JA, Mandel SJ. Thyroiditis after pregnancy loss. J Clin Endocrinol Metab. 1997; 82(8):2455-7. [PubMed: 9253317] 
60. Chang DL, Leung AM, Braverman LE, Pearce EN. Thyroid testing during pregnancy at an academic Boston area medical center. J Clin Endocrinol Metab. 2011; 96(9):E1452-6. [PubMed: 21715539]

61. Baskin HJ, Cobin RH, Duick DS, Gharib H, Guttler RB, Kaplan MM, et al. American Association of Clinical Endocrinologists medical guidelines for clinical practice for the evaluation and treatment of hyperthyroidism and hypothyroidism. Endocr Pract. 2002; 8(6):457-69. [PubMed: 15260011]

62. American College of Obstetricians and Gynecologists. ACOG Practice Bulletin Number 37, August 2002. Clinical management guidelines for obstetrician-gynecologists. Thyroid disease in pregnancy. Obstet Gynecol. 2002; 100(2):387-96. [PubMed: 12166417]

63. Abalovich M, Amino N, Barbour LA, Cobin RH, De Groot LJ, Glinoer D, et al. Management of thyroid dysfunction during pregnancy and postpartum: an Endocrine Society clinical practice guideline. J Clin Endocrinol Metab. 2007; 92(8 Suppl):S1-47. [PubMed: 17948378]

64. Vaidya B, Anthony S, Bilous M, Shields B, Drury J, Hutchison S, et al. Detection of thyroid dysfunction in early pregnancy: universal screening or targeted high-risk case finding? J Clin Endocrinol Metab. 2007; 92(1):203-7. [PubMed: 17032713]

65. Negro R, Schwartz A, Gismondi R, Tinelli A, Mangieri T, Stagnaro-Green A. Universal screening versus case finding for detection and treatment of thyroid hormonal dysfunction during pregnancy. J Clin Endocrinol Metab. 2010; 95(4):1699-707. [PubMed: 20130074] 